\title{
The Role of Culture and Identity in Relations Between Iran and the United States of America
}

\author{
Ahmad Jansiz ${ }^{1}$ \& Samereh Fasihi Moghaddam Lakani ${ }^{2}$ \\ ${ }^{1}$ Political Science, University of Guilan, Rasht, Iran \\ ${ }^{2}$ Independent Researcher on International Relations, Rasht, Iran \\ Correspondence: Ahmad Jansiz, Department of Political Science, Faculty of Humanity, University of Guilan, \\ Rasht, Iran. Tel: 98-912-384-48-35. E-mail: jansiz@guilan.ac.ir
}

\author{
Received: February 15, 2015 Accepted: March 9, 2015 Online Published: March 17, 2015 \\ doi:10.5539/ach.v7n2p21 URL: http://dx.doi.org/10.5539/ach.v7n2p21
}

\begin{abstract}
The interwoven relations of the two longstanding strategic allies is still continuing after the lapse of thirty-six years of the Islamic Revolution of Iran and have occupied the minds of many political thinkers from the past years to the present time and have forced them to investigate the causes of the continuing tensions between Iran and the United States of America. However, this study aims at investigating the role of culture and identity in the bilateral relations of the two countries. The author tries to answer this question by using the theory of Constructivism stating that how culture and identity affect the relations between Iran and the United States of America. Besides, the required data were collected through library references and the research is a descriptive - analytical case. It seems that culture and identity because of playing an important role in the definition of "self", "other" and "interests" of the Islamic Republic of Iran and the United States of America, can be considered as one of the main reasons for the continuing tension between the two countries. The findings show that, cultural values and the identity components of the Islamic Republic of Iran have challenged the unclaimed domination of the United States of America and have affected the national interests and the security of this country through. Accordingly, the United States of America in the past thirty-six years has been challenging with Islamic Republic of Iran.
\end{abstract}

Keywords: culture, identity, constructivism, international relations, globalization, foreign policy

\section{Introduction}

Limited relations between Iran and the United States of America that had stated with signing a treaty of friendship and commerce between the two countries from the Year 1856 (Hunter, 2010: 34) expanded such that after the onset of the Cold War II, Iran was considered as one of America's strategic allies in the Middle East. But the dissatisfactions created among the people with domestic tyranny and dependence of the Shah's regime that the US officials were not unaware of it (Ganji, 2006: 1) led to the overthrow of the Shah and the establishment of the Islamic Republic of Iran in February 1977. Ultimately after the U.S. Embassy Capture to Iran and the beginning of the hostage-taking crisis, diplomatic relations between the two countries were interrupted by the United States of America on 8 April 1980 and this political relationship is still broken and hostile until today.

Many domestic and foreign scholars have investigated on the relationships between the United States of America and Iran from different perspectives and the reasons of the continuing tensions between the two countries. For example, Shireen Hunter knows the reason of tensions in the existence of bitter memories between the two countries and its impact on the mutual relations, e.g., the coup against Mossadegh's government in 1962, overthrowing the Iranian passenger plane and attempting to establish the Nojeh Coup are among bitter memories of Iranians about America; while, capturing America's Embassy and holding it's staff by Iranians that led to America's humiliation at the international arena, the role of Iran in the Lebanon's events and hostage-taking some other American members (Hunter, 2010: 33-77) are considered among the bitter memories carved in the minds of Americans toward Iran. But Ali Ansari believes that these historical records are as pouring gasoline on the fire of animosity between the two countries and reiterate that incoherent structure of decision-making in Iran and participation of different parallel actors and organizations are the main obstacles for building trust and strengthening relations between the two countries of Iran and America (Ansari, 2006: 155-170). 
Mohammad Javad Zarif, the Secretary of State of the Eleventh Government of Iran, knows the following cases as the main causes of mistrust and confrontation between Iran and America: "Accumulation of unresolved negative impacts in the history of the two countries", "wrong impressions especially in America toward the behavior of Iran", "Misunderstandings arising from indirect interactions", "Misperception of each side toward the failure of the counterpart when announcing the readiness to (political) interaction" and finally "suspicions over short and medium-term goals and intentions". Moreover Zarif believes that America needs a tool like "an enemy" to govern and continue its global interactions and also ally the countries of the region with its policies; while, it believes that the Islamic Republic can create fundamental problems for the West particularly the United States of America due to offering "a new paradigm for governing" and claiming to have a "global mission" like America does and therefore is interested in technological progress of Iran and has been attempting to introduce it as an "international security threat" from the beginning of the Islamic Revolution to the present time according to the mentioned reasons (Zarif, 2007: 73-85).

Nowroozi \& Mousavi know the main reason of the deadlock between the two countries in the lack of mutual trust, doubt of the two countries toward the sincerity of the counterpart as well as lack of trust to the other side's wants to do something positive (Mousavi \& Norouzi, 2010: 122-140). Ultimately, Hasan Rouhani for explaining the reason of conflict between the two countries, after mentioning historical, ideological \& religious roots (Rouhani, 1992: 28) argues that the reason of the animosities of America against the Islamic Republic of Iran is that Iran as a revolutionary and independent country is standing in front of the New World Order of America and has repeatedly humiliated this country and has been generating anti-American policy in the Muslim World and is considered as the main cause of insecurity of Israel; moreover, Iran is a country that is threatening America's vital interests in the Middle East (Rouhani, 2001: 16) based on the mentioned reasons.

He knows "national authority" as one of the most stressful items between the two countries and believes that the accusations attributed to Iran from Clinton's presidency era, i.e., the human rights, proliferation of mass destruction weapons, support for terrorism and preventing the peace process, with political motivation and reflects the need of America to secure the space of Middle East for its expansionism motivations (Rouhani, 2003: 23-19).

However, this study aims at evaluating the impact and role of culture and identity in relations between the two countries. Cross-sectional method is applied in this research and collecting data is performed through library references. Using theoretical framework of Constructivism of the unit level, the author seeks to answer this question that why and how culture and identity affect the relations between Iran and the United States of America. To achieve this goal, after presenting a brief description of the Constructivism approach of the unit level, we act to define the constructive elements of the Islamic Republic of Iran and the United States of America's identity and the role that culture and identity play for the relations of the two countries.

\section{Theoretical Framework: Constructivism}

Explaining the role and place of culture in international relations is very important. Especially, proposing the recent theories in international relations has led to strengthening the role of culture as a basis for analyzing international issues. While, classical thinkers and scholars of international relations have emphasized on the political, security and economic areas to explain the factors affecting the international issues, some of them have found that achieving the depth of international relations is possible only with considering these areas. This group of thinkers seeks the answers of their questions within their culture and cultural issues and decided to pay a special attention to the cultural issues in addition to adoption of major political, security and economic factors, and study this important dimension of social life in international relations. These thinkers see the culture as an important phenomenon that is hidden in the perspective of classical thinkers. Their main criticism is to the previous theories that have not paid attention to the role of culture at the international relations. Theses scholars for explaining the international issues with considering the culture beside the political, security and economical issues led to emergence of two ideas. Some people construed culture as the area of conflict and the foundation of tensions in the international relations area and somebody in contrast to the first group believe that culture is the area of dialogue, interaction and integration in the field of international relations. Thus, it appears that the place of Constructivism theory is unique.

Constructivism is a metatheoretical model in social science and an in-depth analysis of issues of ontology and epistemology that its followers can be located in the middle of the two main parts, i.e., realism and liberalism in terms of metatheoretical model concepts in the mid-range of naturalists/ positivists on the one hand and poststructuralists on the other hand and in the substantive issues of International Relations (Moshirzadeh, 2011: 323). This approach uses the constructed and changing nature of identity, opportunity and possibility of change in the international system (Mansbach, 2002: 1-5) and by challenging the assumptions of rational ontology, offers an 
approach based on principles and different assumptions of the original currents and tries to delineate how factors such as culture, religion, ethnicity, gender, race and nationalism affect the foreign policy through an "Approach to Identity Politics" (Dehqani Firoozabadi, 2009: 43).

Constructivists for analyzing foreign policy of the countries and investigating the materialization of their interests in the international system, instead of focusing on the goals the governments are pursuing in the international system, try to investigate the definition that each state offers about its identity to specify the goals and interests they are following in the international system (Kubalkova, 2001: 115). Because in Constructivists' idea "identity" is a set of beliefs about "self", "others" and the interactions between them (Fearon \& Wendt, 2005: 64) and is strongly influenced by culture and plays a decisive role in determining the interests of a country, Pouliot knows Constructivism possessing a certain way of reasoning that is based on the meta-theoretical commitments and assumptions like the possibility of recognition despite its construction, the coincided importance of material and immaterial realities and the emphasis on the construction of social reality and the existence of interactive formative relationship between knowledge and social reality (Pouliot, 2007: 361). In fact, ignoring the impact of culture and identity as a social phenomenon and an important factor in determining the interests and foreign policy of countries is one of the most important constructivists' critics to the mainstream theories (Lapid, 2001: 15).

It should be noted that Constructivism theorists are divided into several types based on the level of analysis, methods and strategies. Ted Hopf, divides the non-essential current or critical views of International Relations at the two categories of extreme Constructivists and conventional Constructivists (Hopf, 1998: 171). While, conventional Constructivists are divided to three categories of "systemic", "unit level" and "holistic" in terms of analysis level. Alexander Wendt as the most important systemic Constructivist, knows this level of analysis enjoying a social nature and believes that mental vision structure of the international system is based on a common understanding that have a fundamental role in shaping the identity and subsequently delineating the interests of states (Wendt, 1999: 385). Peter Katzeneshtein emphasizes on the internal factors of developing the identity of the government (Smith, 2001: 235). He believes that culture, shaping and arranging are crucial in the definition of "self", "other", interests, and orientations and behavior of foreign policy of a state in the international area (Katzeneshtein, 1998: 28). Friedrich Kratochwil and John Ragy as two members of holistic Constructivism theory know the social order including two faces of internal structures and processes and believe that the separation of domestic and international spheres is a rare historic structure built around the state - nations enjoying the sovereignty (Kratochwil \& Ruggie, 1986).

However, the authors continue their efforts to use the assumptions of Constructivists of unit level to identify the internal components influencing the political culture of the Islamic Republic of Iran and the United States of America. So that, to determine the role of culture in shaping the identity of the two countries and the definition provided of "self" and "other" and the benefits expected for themselves at foreign policy arena explain how the culture and identity affect on the relationship between the two countries.

\section{Culture and World Politics}

The relationship between culture and politics has long been neglected until the first time "Ishumi", the French sociologist, said that culture also has a political dimension. Because culture has hid itself behind all individual and social actions and because of influencing the social behavior, affects political behavior significantly as well. However, it took many years until the relationship between politics and culture and their impression on each other in the field of international relations to be designed. And only in the 70s and $80 \mathrm{~s}$ of the twentieth century, some experts' opinions were focused on international relations that culture influences on behavior and actions of foreign policy and international behaviors of the countries in global politics area basically. This has led to emergence of a branch of knowledge entitled "Sociology of International Relations" to study the influence of culture and politics in political behaviors in the field of international relations and global politics. Thus, the researchers such as Raymond Aron, Marcel Merle, Stanley Hoffmann, etc tried to raise and evaluate the assumptions about the impact of states and the role of national and cultural norms and values and gradually, this issue was welcomed among scholars of international relations.

Some scholars of the culture field believe that the impact of culture and moods of nations and also the influence of national culture, not only do affect on foreign policy and international behavior, but also is influential on the manner of war and defense. These theories conclude that all nations have their own culture and style even in fighting and developing a strategy. A specific method of every nation is different with that of other culture. Stanley Hoffmann also believes that the mood of a nation influences on their political behavior. He follows this vision with an example of Americans' political behavior in the world politics area. He believes that the main reason for U.S. involvement in international affairs has cultural roots; because the Americans feel a responsibility on their 
shoulders in this regard and they see themselves on an island that nothing is threatening them, and some people are drowning and around them in the need of their help. Therefore, the intervention of the Americans (in the international affairs) is not due malice but is a part of their political culture. They know that their moral duty is to participate in the political issues of the world and they construe this intervention as a favor for other nations (Naghibzadeh 2002: 8-6). So, today we see that culture has attracted the attention of politicians. This is not to say that politicians are always proponent of culture, but it means that culture is known as a policy tool and is construed as a social ideal phenomenon that the government is bound to promote it.

\section{The Role of Culture and Identity in Relations Between Iran and the United States}

In the nineteenth century and the early years of the twentieth century, Iran that was called Persia in that time was a country outside the United States of America's diplomatic interests .So no kind of crisis that could engage the two countries in some way could be found then. Hunter knows the initial contacts of the two states in 1851 AD. In that year, Iran sent its envoy to the Ottoman court to meet America's ambassador to Constantinople to buy warships from America to better protect the Persian Gulf and its islands and ports and support its naval businessmen. Hunter believes that Iran's reformist prime minister -Amir Kabir- was very hopeful that America's interests reduce the damaging Anglo-Russian rivalry in his country. If we accept the claim of Mrs. Hunter about Amir Kabir, this Iranian diplomat's perspective at the United States of America can be considered as a benevolent "other" or a third force which could intensify "self" of the Iranians toward "other" colonials such as the Russia and England. Hunter believes that Iran and America in 1856 signed the first treaty of commerce and friendship. However, until the beginning of World War II these relations remained limited (Hunter, 2010: 34).

According to the available documents, in the first years after World War I, the United States of America played a more active role in the affairs of Iran and in some cases even countered with the perceived threats against independence and sovereignty of this country. Perhaps this can be considered as one of the factors that led to Iran's seeking help from America for managing its financial affairs and sending a delegation headed by Millspaugh from the United States that faced defiance of influential opposition forces in Iran. Although the mentioned oppositions occurred from the European threatening "others" and eventually prompted it to return to their homeland and since then the United States of America did not see any necessity for a particular presence in Iran. Until after World War II, Soviets that was denying leaving Iran left this country after receiving President Truman's ultimatum in 1946 and withdrew its forces (Tirani, 1999: 71) and from this date, the United States of America was converted into a benevolent "other" for Iranians against the threatening "others" such as the Soviets and Britain.

This view toward America can be seen even after the accession to power of Mossadegh. Mossadegh on 1951/07/23, in his message to President Truman, asked for America's assistance to Iran and the peaceful settlement of the question of oil and exposing conspiracies of the UK in Iran. Mossadegh also declared that Iran is willing to sell oil to America. But the United States overthrew Mossadegh in Operation Ajax and brought Mohammad Reza Shah to power. There are two opinions about this America's treatment against Mossadegh's government. One of them is the problem of obtaining a share of the oil and preventing Iran from falling into the lap of communism. However, the Iran Coup, 1953 can be the beginning of a change of identity in the minds of people and changing America from a benevolent "other" to a "dangerous enemy" (SoltaniNejad \& Shapuri, 2012: 115-116). In other words, after this event, the United States of America is known as a threatening "other" and "enemy" of the Iranian people that afflicted heavy blows to the body of Iran's independence.

At the same time, because of the arbitrary actions of the Shah of Iran who came to power with the help of the Americans and some of his modernistic actions that were against the teachings of Islam as well as establishing political relation with the Zionist regime that in addition to opposition to Islam was against the justice-seeking and anti oppression identity of the Iranian people, Iranians defined "Self" in contrast to two "others" and defined Shah of Iran as a domestic "other" who was against the teachings of Islam and willing to the principles of the ancient Iran era and also the United States of America and its strategic ally, Israel, as a foreign "other" that were the greatest foreign enemies of Iran and this trend ultimately led to the Islamic Revolution. Accordingly, many writers know Islamic Revolution of Iran possesing two dimensions of fighting with domestic tyranny and foreign colonization (America in particular) and believe that "the fight against America in the early years of this movement was considered as a pivotal and central slogan" (Rouhani, 1992: 29-28).

After the Islamic Revolution of Iran on 1979/05/17, America's Senate passed a resolution proposed by Senator Jacob Javits that would criticize the courts of revolution verdicts associated with the executions carried out in Iran and this (intervention) caused dissatisfactions inside Iran. Ayatollah Khomeini on 1979/05/19 in his speech said: "What are the benefits arising from relations with America for us?" (Khomeini, 1992, Vol. 7: 357) This speech caused massive protests against America on 3 June. Sometime later with granting permission to Shah for entering 
the United States and recalling the events of Mossadegh era, Iranians thought that the United States intends to overthrow the Revolution and restore the Shah to power and such suspicions were aroused with some of the actions of Interim Government of Iran. These factors finally led to the U.S. Embassy Capture and the beginning of the Hostage Crisis that led to the cessation of diplomatic relations between the two countries eventually. For better understanding this issue that why despite the much changes in these two countries the conflict is still continuing and what role culture and identity play in the relations, introducing two elements including the identity of the United States of America and the Islamic Republic of Iran is required.

Islamic Revolution was established in Iran in response to domestic tyranny and foreign colonization (especially by America) and challenged not only communist ideology but also liberal values in the bipolar era by providing a new model for life and governance and raising the claim of having a "global mission" (to establish some ideological changes in the world). Therefore, the United States and the Soviet Union, construed Islamic Republic of Iran's identity a threat for themselves and therefore by the beginning of Gorbachev's rule, the two countries were informally allied with each other in the war against the Islamic Republic. In that period, Imam Khomeini because of the support of the most Western countries and international organizations' unfair treatment including the United Nations, defined the "Islamic" identity of Iran against the infidel "others" and announced the imposed war as the war of Islam and blasphemy (Khomeini, 1992, J. 13: 221-226). Therefore, considering the cultural identity, Islamic Republic of Iran was located in the right front and Saddam and his supporters were considered the "others" classified in the wrong front (Dehqani Firoozabadi and Wahabpur, 2012: 108-115). So America, in this period, in addition to the measures in 19 August 1953 Coup, the suppression of the revolutionaries, and supporting Shah, with supporting invasion of Iraq and the role it played in destruction of Iran Ajr Ship, Salman (Oil) Platform and overthrowing the Iranian passenger plane, reproduced and re-established its identity as a threatening "other" and a dangerous enemy in front of revolutionary and Islamic identity of Iranian people.

\section{Relations Between Iran and America After the Cold War}

The role of cultural conflicts that was inconspicuous or invisible raged after the Cold War. Nations conflicted together at the local level, but a broader tension existed between global and local forces. Culture of West was the dominant force in the globalization process so that it seemed to be trying to unify human experience. This issue, led to expansion of conflicts and cultural disputes. Also the end of the Cold War was coincided with the fundamental change of the forces determining the global politics. Victory of West also accelerated the revolution of information and communications technology. Changing patterns of global and national policy made the cultural understanding more necessary. Thus, gradually, we observed the formation of cultural dialogue in world politics in which the soft power and culture enjoy the central position. Because in cultural dialogue, interactions and relations between countries have cultural roots, and cultural theories explain and justify the political behaviors and actions in the field of international politics, the theories like Fukuyama's "End of History" and the Huntington's "Clash of Civilizations" theory strengthened the place and role of culture and soft power in international relations and equations. At this point, given the dominance of liberal capitalism, New World Order, is raising and forming. The amount of cultural influence hid in the new hegemony is unprecedented. This hegemony, challenged culture and social order of the most communities. In contrast, some resistances emerged in construction of culture by some states of rich culture and civilization. This has led to a new type of conflicts caused through soft power in the world's scope in which the tools themselves would require special facilities. What Fukuyama named "liberal idea" in "End of History" theory, is a mix of liberal democracy and market economy. This is as the end line for political and social development history and this idea has been challenged by scholars as well.

In the closing years of the Cold War, the United States of America, due to the changing global situation, offered a different definition of "self" and "other" and by the collapse of the Soviet Union that led to disruption of the bipolar order the United States was placed in a situation that could deal with globalization issues shaping the identity of "self", i.e., the American way of life with all its valuable cargos in the world scope. In this period, the attention of authorities in America was focused on the fight against terrorist activities, preventing the transport, distribution and production of drugs and preventing the spread of nuclear weapons, especially wandered weapons of the former Soviet Union and unlike to past, U.S.A was not a threatening "other" for the Soviet Union and communist ideology because the nature of security threats had changed and the wide variation in the distribution of global power in the early 1990s led to creation of necessity to redesign the United States of America's overall strategy (Gaddis, 2005: 2).

In other words, the United States of America after the Soviet Collapse, due to the need for an enemy to establish its identity changed the concept of "other" from the Soviets to "terror and drugs" and with eliminating the threat of the Red Enemy selected the "other" enemies of second or third order powers or even subcultures and sub-identities among new threats to America's interests. So America's foreign policy in the Third Millennium is a policy aimed at 
identification. However, specific areas such as Middle East are vulnerable to be identified for terrorist attacks (Emamzadehfard, 2004: 113-112).

In this period, the Islamic Republic of Iran in the national security strategy documents published between the years 1993-2001 has been charged in four cases including pursuing weapons of mass destruction, supporting terrorism, disrupting the Middle East peace process and attempting to undermine regional governments. In other words, the Islamic Republic of Iran in this period is known as a threatening "other" to America's interests in Middle East region and in Document 1994 is entitled a "potentially hostile regional power" and emphasized on "Dual Containment" approach (NSS, 1994: 25) for tackling it and changing its behavior toward the above four cases as well as human rights issue.

Moreover in a document of two years later, the Islamic Republic of Iran was mentioned as a "principal threat for peace in the Middle East and a major threat to innocent civilians" (NSS, 1996: 16) Moreover, the Document 1977 stresses on containing Iran as well as Iraq and supporting the regional allies. Besides, the flow of oil among the threats of the two countries is arisen among the priority of the United States of America (NSS, 1997: 32). In other words, in Clinton era, the Islamic Republic of Iran is always considered as a threatening "other". Iranian supreme leader considers the United States' charges and the multiple-approach of this country due to the hostility with the Iranian Islamic identity of people that leads to the spirit of independence and effectiveness of the Islamic Revolution on "Muslim Awakening" and revival of Islamic thought.

With accession to power of President Khatami and after his speech at the UN in 2000, Clinton and his Secretary of State sent a positive pulse to re-establish the relationship between the two countries (Katzman, 2012: 8) but the pressure of the Zionist lobby and other internal factors, overshadowed these efforts and after September 11, 2001 because of the same mentioned culture and identity conflicts after the interview of MKO group in the early 2000s, Khatami's efforts for normalizing relations went to the sideline and nuclear issue became one of the most important challenges facing Iran's foreign policy (Entessar,2009: 26) and the United States of America at that time while defining the Islamic world as a fundamentalist "other" called Islamic Republic of Iran the axis of evil and defined it as one of the enemies of the United States (Moshirzadeh \& Salavati, 2012: 89).

Accordingly, although in the national security Document 2002 (NSS, 2002) the name of the threatening countries have not been cited, but George Bush's speech to Congress on January 29, 2003 in which called Iran, Iraq and North Korea as the axis of evil (Rouhani, 2001: 19) confirms this claim. So, after September 11 event, and under the influence of neo-conservatives' perspective and efforts by Jewish and Zionist lobby, Islamic fundamentalism that challenge America's acceptable values and nuclear weapons was considered the most important "other" and hostility that endangers interests of the United States. Additionally, the Islamic Republic is introduced at the peak of threatening "others" (NSS, 2006: 20,7) that the United States of America should apply all its ability to change the political system of this country in long-term (Jansiz, 2011: 209). At the same time, Ayatollah Khamenei appraised America's allegations baseless and motivated by hatred of America with the Islamic culture and revolutionary identity and stressed that the Islamic Republic of Iran, due to its independence-seeking feature and anti-authoritarian and strength spirit that make it a model for other countries and a source of emitting Pure Mohammadian Islam is subject to the animosity of America (statements of Iranian supreme leader 2003/05/12).

After accession to power of Obama, despite his widespread publicity for changing the approach of this country (toward Iran), we see a continuation of past policies at the level of goals (Abdullah, Ismaili, 2012: 121) and the published national security documents of Obama's era confirm this claim as well (NSS, 2010: 23-24). Iranian Islamic identity and its revolutionary spirit which prevented the abuse and exploitation of Iranian nation in Pahlavi regime era endangered interests of the United States and affected their national security.

Iranian independence-seeking spirit and emphasis to resistance to all imposed pressures and sanctions is originated from the Iranian revolutionary and Islamic identity and this fact that the Islamic Republic of Iran has proposed a new model unlike the liberal model, has raised this country as a threatening "other" that similar to United States of America construes a global mission for itself because of challenging the fundamental values of America. In addition to the aforementioned points, hostility towards Israel that is originated from justice-seeking spirit of Iranians and the culture of supporting the oppressed people caused by teachings of Islam are among other items that provoke Zionist lobbies to announce Islamic Republic of Iran as a dangerous threatening "other" using the influence they have among the United States of America's elites and institutions. Accordingly, the leader of the Islamic Revolution of Iran knows Israel issue and the Islamic Republic of Iran as one of the most important reasons of the United States of America's animosity (Khamenei, 2006/03/21) .Until Islam and the teachings of Islam dominate on Muslim people's thinking and lead to strength and independence-seeking spirit and prevent them from 
being exploited, hostility of the United States toward Iran will continue and this country will remain as an dangerous "other" for the Islamic Republic.

\section{Conclusion}

After the Cold War and with the disappearance of an ideological enemy like Soviets, the United States of America, self-chosen of God, defines its liberation-loving and exceptional identity located in the axis of right, against the fundamentalist, terrorist and Muslim "other" located on the axis of evil and under the inductions of the domestic, regional and international factors, knows Islamic culture and Islamic revolution, and historic identity of Islamic Republic of Iran and subsequently national security threatening factors for the national interests. Thus, despite Islamic Republic of Iran's strength points compared to other Middle Eastern countries, is challenging with the identity and values of this country and defines it fit with the ups and downs of its presidents' personality as an "enemy" or threatening "other" that endangers America's interests.

In contrast, Islamic Republic of Iran due to the United States' performance before and after the Iranian Revolution has defined this country as the most important (threatening) "other" and the enemy of its identity that this inimical image with the America's actions against the Islamic Republic of Iran during the thirty-six year period after the revolution is constantly fixing and reproducing. So opposition to America is as a factor for Iranian people's unity and somehow will pave the way to reach their continued independence-loving identity (against the colonizers such as America). The identity of protecting the weak and the oppressed (in contrast to the United States' supports of Israeli crimes against the Palestinians) and anti-imperialistic identity (against the United States that is a clear example of arrogant) are the identities of resistance of Iran to America's bully actions. Accordingly, culture and identity can be introduced as one of the most important and influential factors of continuing tension in relations between Iran and the United States of America.

\section{References}

Ansari, A. (2006). Iran and U.S In The Shadow of 9/11: Persia and Persian Question Revisited. Iranian Studies, 39(2). http://dx.doi.org/10.1080/00210860600628716

Dehqani Firoozabadi, S. J., \& Wahabpour, P. (2012). Ontological security in foreign policy of the Islamic Republic of Iran. The Research Institute for Strategic Studies. (in Persian).

Emamzadehfard, P. (2004). America's National Security Doctrine: Past, Present and Prospects. in Book America (7) Special America's National Security Doctrine, Tehran: Abrar-e- Moaser International Studies and Research Cultural Institute. (in Persian).

Entessar, N. (2009). Iran Nuclear Decision Making Calculus. Middle East Policy, XVI(2). http://dx.doi.org/10. $1111 / \mathrm{j} .1475-4967.2009 .00389 . x$

Fearon, J., \& Wendt, A. (2005). Rationalism V. Constructivism: a Skeptical View. in Handbook or International Relations, London: Sage Publication.

Gaddis, J. L. (2005). Grand Strategy in the Second Term, Foreign Affairs, 48(1).

Ganji, B. (2006). Politics of Confrontation the Foreign Policy of the USA and Revolutionary Iran. Tauris Academic Studies, New York.

Hopf, T. (1998). The Promise of Constructivism in International Relations Theory, International Security, 23(1). http://dx.doi.org/10.1162/isec.23.1.171

Hunter, S. (2010). Iran Foreign Policy in the Post Soviet Era Resisting the New International Order, Praeger.

Jansiz, A. (2011). Identity-Orientation in America's Foreign Policy and its Impact on Iran's Nuclear Program (2001-2008). World Politics, Volume One, Issue 2. (in Persian).

Katzeneshtein, P. (1998). Cultural Norms and National Security: Police and Military in Japan. New York: Cornell University Press.

Katzman, K. (2012). Iran: U.S. Concerns and Policy Responses, Congressional Research Service.

Khamenei, S. A. (ND). In The office of the supreme leader Sayyid Ali Khamenei. Retrieved from www.leader.ir

Khomeini, R. (1992). Sahifah Imam (Letters of Imam), Tehran: Ministry of Culture and Islamic Guidance. (in Persian).

Kratochwil, F., \& Ruggi, J. (1986). International Organizations: A State of the Art or an Art of the State. International Organizations, 40. http://dx.doi.org/10.1017/S0020818300027363 
Kubalkova, V. (2001). Foreign Policy in Constructed International Policy Constructed World. Armonk: M.E. Sharpe.

Lapid, Y. (2001). Introduction in Identities, Borders and Others: Rethinking in International Relations Theory. Minneapoliss: University of Minneapolis Press.

Mansbach, R. W. (2002). Deterritorializing Global Politics. In Vision of International Relations: Assessing an Academic Field. Columbia: Columbia University of Press.

Moshirzadeh, H. (2011). A Breakthrough in the Theories of International Relations. Samt Publications. (in Persian).

Moshirzadeh, H., \& Salavati, F. (2012). The Muslim world / other Fundamentalist and Iconic American Ideal in America's foreign policy. Foreign Relationss Journal, VI(1). (in Persian).

Mousavi, M. A., \& Norouzi, Y. (2010). Iran-U.S Nuclear Standoff: A Game Theory Approach. Iranian Review of Foreign Affairs, 1(1).

Naghibzadeh, A. (2002). The Influence of National Culture on the Political Behavior of Iranians. Tehran, Capital of Recognition of Iran and Islam. (in Persian).

Pouliot, V. (2007). Subjectivism: Toward a Constructivist Methodology. International Studies, 57. http://dx.doi.org/10.1111/j.1468-2478.2007.00455.x

Raji, M. M. (2012). Interview with Zarif, Mohammad Javad., "Mr. Ambassador", Tehran: the Ney Publications. (in Persian).

Rouhani, H. (1992). The New World Order and the Place of Islam in the Tomorrow Geopolitics. Parliament and Pazhuhesh, 5. (in Persian).

Rouhani, H. (2003). Serving Movement from Slogan to Conduct. Quarterly Journal of Rahbord, 33. (in Persian).

Rouhani, H. (2008). The Future of Relations between Middle East and West, Foreign Relations Journal, I(2). (in Persian).

Rouhani, H. (2011). National Security and Nuclear Diplomacy. Center for Strategic Research. (in Persian).

Rouhani, H. (2011). The Strategy of Iran's Recent Threats against Book America. Quarterly Strategy, 24. (in Persian).

Smith, S. (2001). Reflectivist and Constructivist Approaches in International Theory. Wiley.

Soltani Nejad, A., \& Shapuri, M. (2012). Iran and America: Negative Cycle of Construction and Continuing Nuclear Dispute, Foreign Relations Journal, V(1). (in Persian).

The White House. (1994). NSS (National Security Strategy of the United States of America).

The White House. (1996). NSS (National Security Strategy of the United States of America).

The White House. (1997). NSS (National Security Strategy of the United States of America).

The White House. (2002). NSS (National Security Strategy of the United States of America).

The White House. (2006). NSS (National Security Strategy of the United States of America).

The White House. (2010). NSS (National Security Strategy of the United States of America).

Tirani, B. (1999). Chronology of Relations between Iran and America (1832-1999 / 1248-1377). Tehran: Ministry of Foreign Affairs, Publications and Printing Center. (in Persian).

Wendt, A. (1999). Social Theory of International Politics. Cambridge: Cambridge University Press. http://dx.doi.org/10.1017/CBO9780511612183

Zarif, M. J. (2007). Tackling the Iran-U.S. Crisis: The Need for A Paradigm Shift. Journal of International Affairs, 60(2).

\section{Copyrights}

Copyright for this article is retained by the author(s), with first publication rights granted to the journal.

This is an open-access article distributed under the terms and conditions of the Creative Commons Attribution license (http://creativecommons.org/licenses/by/3.0/). 